\title{
EL DE OFFICIIS O LOS DEBERES DE SAN AMBROSIO*
}

El profesor y traductor Julio Picasso no descansa. Hace año y medio nos brindó la traducción de la Eneida, de Virgilio, esmerada y bella traducción enriquecida con su amplia introducción y abundancia de notas. Culminó así la traducción de toda la obra de Virgilio. Unos meses más tarde nos presenta la traducción del libro De magistro, de santo Tomás de Aquino. Hoy nos ofrece Los deberes, el De officiis de San Ambrosio. Incomprensiblemente — ¿no diremos también escandalosamente? - es la primera traducción completa, si estamos bien informados, que se hace al español. Es de reconocer muy laudablemente el esfuerzo editorial que hace la Universidad Católica Sedes Sapientiae de Lima.

Es un libro muy bien presentado, de gran formato, amplio, de muy clara y cómoda tipografía y distribución para el lector. Lo precede una biografía del santo que da idea suficiente de la personalidad de Ambrosio y de las circunstancias que rodearon su vida y su «aclamación» para obispo de Milán.

Con el título De officiis o Los deberes, conoceremos varios libros de la época clásica. El escrito de san Ambrosio se inspira en Cicerón y sobre todo en la Biblia de la que toma los ejemplos y, también, generalmente, el sentido de sus palabras.

San Ambrosio quiere cumplir su deber episcopal escribiendo un libro, publicado hacia el 389, sobre los deberes de los clérigos, aunque extendido a todo cristiano. Dice que Panecio, Tulio y otros han escrito sobre el tema con el fin de educar a sus hijos. Tomando pie de esos autores escribe acertadísimas y perdurables frases, con no mejor urgencia de ser enseñadas hoy que ayer. "Yo, hijos míos, lo hago para vuestra formación. No os amo

* Donato Jiménez Sanz, secretario General de la Facultad de Teología, Pontificia y Civil de Lima. 
menos por haberos engendrado en el Evangelio que si os hubiera tenido de una esposa. La naturaleza no es más impetuosa para amar que la gracia».

Con ese interés de sano celo, el obispo de Milán escribe estás recomendaciones que resultan a veces abundosas e insistentes, pero cuya solicitud paternal y pastoral le lleva a exponer y recomendar como deberes la exigencia de las virtudes cristianas y humanas. A modo de programa, se inspira en el salmo 39 (Yo me dije: Vigilaré mi proceder para no fallar con la lengua), que recomienda aprenderlo de memoria. Las enseñanzas de este salmo impelen a escribir sobre los deberes. Hablará, como los filósofos, de lo bello y lo conveniente, pero a diferencia de ellos los estudiará por así decir, sub specie aeternitatis, con mirada trascendente; así dará plena profundidad y sentido a esas dos importantes categorías.

San Ambrosio no es orador como Cicerón ni poeta como Virgilio ni retórico como Agustín, pero es más que un poco de todo eso. Con un estilo que podríamos llamar único nos presenta un conjunto de reflexiones éticas y morales generalmente derivadas de los textos de la Escritura, como es deber natural del obispo, y adobadas con no pocas alucinaciones y citas de los autores clásicos. Hace moral, pedagogía, apologética, teología y amena literatura.

65. Hablando sobre la modestia, que él deriva de «modo» de conocer lo conveniente, hace unas atinadas consideraciones tanto en el plano de la virtud cristiana como bajo los aspectos sicológicos y sociales: «Hay que mantener la modestia en el movimiento, en los gestos y al andar. En efecto, se discierne la disposición del alma en la actividad del cuerpo. Lo intimo y lo oculto (1 Pe 3 4) se deja ver a partir de la actitud: ligero, fanfarrón, apasionado o, al contrario, serio constante, casto maduro. El movimiento del cuerpo es un modo de lenguaje del alma» (71). Desechando pretensiones, abalorios y exterioridades, a propósito de las palabras de San Pedro en su citada epístola, hace valer la sinceridad y mansedumbre del «hombre oculto en el corazón», del hombre interior, estimado grandemente por Dios.

$Y$ no tiene reparo en traer ejemplos precisos de su actuar personal tratando de corregir comportamientos o maneras extravagantes y llamativas. 
"Os acordáis...», dice, cuando no admití al clero a uno por sus ademanes inconvenientes, y a otro que con solo verlo me ofendía como una bofetada. Y asegura: «No me equivoqué». Ambos abandonaron la iglesia.

Es muy probable que Agustín, el retórico de tagaste llegado de Cartago, hubiera oído en varias ocasiones predicar al obispo sobre este tema en su asidua concurrencia a la catedral de Milán. El joven profesor africano pasó unos tres años en la ciudad de Milán, residencia del emperador, y setíase tan gusto oyendo los sermones del obispo - delectabar suavitae sermonisy disfrutando las melodías de los salmos y los himnos que el propio obispo componía (Conf. V 1323) .

Sin duda el consejo que el propio san Agustín nos dejó en su Regla es una resonancia bien asumida y casi literal de las palabras y comentario ambrosiano sobre el tema: In incessu, statu, habitu, in ómnibus motibus vestris, nibil fiat quod cuiusquam offendat aspectum, sed quod vestram deceat Santitatem. Cierto, tenemos bien entendido que el estilo es el hombre, mas por eso mismo, la virtud cristiana y la estética elemental exigen de formadores y educadores corregir ciertas formas desaliñadas que desdicen la seriedad y dignidad que deben ir adquiriendo sus educandos. Si bien la modestia es apropiada para todas las edades y ocasiones, es sobre todo conveniente para los adolescentes y jóvenes (81).

Y aprovecha san Ambrosio la palabra formositas de Cicerón para aplicarla a la modestia que hermosea los rostros y los hace más atractivos. De forma parecida dirá de la honestidad y prestancia en el vestir, o del tono de voz y del saber estar en las atenciones y reuniones.

No podemos menos ponderar las sensatas reflexiones del santo pastor sobre los deberes. Y hoy, más que aún que en su propio tiempo, son de señalar y encarecer. Hoy, que en los medios masivos, interesados en las ruina de valores sustituidos por modas estrafalarias, dan culto a lo feo, a lo antiestético, y quieren pasar por indumentaria (por usar benévolamente un término tradicional), lo zafio, la mamarrachada y el adefesio (83).

90. Y sigue dando sabios consejos trayendo los ejemplos bíblicos, interpretados muchos de ellos de forma muy peculiar, más que con intención 
exegética, con la finalidad de presentar gestos que identifiquen y susciten un comportamiento y mesurado en todos los órdenes.

Podemos afirmar, casi con toda seguridad, que san Ambrosio no conoció la primera obra de Agustín De pulcro et apto, que menciona en las Confesiones (IV 13 20), obra perdida tempranamente. Pero se podría plantear esta pregunta: ¿leyó el obispo de Mián los Diálogos de Casiciaco, escritos en el 386, donde podemos encontrar tantas coincidencias y pensamientos idénticos? ¿Refleja el filósofo africano en esos libros recuerdos y frases oídas en la catedral de Milán? No es de este lugar, pero sería interesante rastrear las posibles influencias entre el De officiis y los Diálogos de Casiciaco.

Es en verdad que Agustín todo es vuelo metafísico; en Ambrosio es sobre todo intimación moral. Pero muchas palabras y frases del discurso son idénticas: Modestia Utique dicta est a modo ('Modestia o moderación y templaza, allí nada sobra ni falta. Ella, pues, comprende la plenitud') (De beata vita, 32 ). Y se aplica, recordando casi toda la letra, uno de los himnos ambrosianos que oía cantar en la catedral y llevaba grabados en la memoria: Christusque noster sit cibus, I potusque noster sit fides, I leti bibamus sobriam, / ebrietatem spiritus. El pueblo bebía de labios de tu piadoso siervo Ambrosiano, 'la flor de tu trigo, la alegría del óleo y la sobria embriaguez de tu vino' (Conf. V 1323 ).

En los libros del segundo y tercero, el obispo mediolanense continúa tratando de la belleza que es que hace la auténtica vida feliz que, en cristiano, constituye ya aquí, en prenda, la vida eterna. En muchas de esas lecciones de san Ambrosio asoman igualmente las coincidencias con el filósofo de Casiciaco . En este serán reflexiones de corte más netamente filosófico, en aquel de intención eminentemente pastoral y educativa de la fe. Y seguirá trayendo abundantes ejemplos de personajes bíblicos, para destacar y alabar la virtud en unos y condenar el vicio y la injusticia en otros. No dejan de percibirse muchas observaciones de agudeza sicológica, como elementos, serena, justa y generosa.

Un libro que juzgamos muy útil, e incluso, necesario en nuestros días, cuando padecemos un rebrote neopaganizante, que condena el 
silenciamiento y parece ir a la demolición sistemática de las virtudes, de la belleza, de rasgos más noblemente humanos que significan a la persona, imagen — ¿habrá que recordarlo? — ¡de Dios!.

Libro de lectura llana y de comprensión facilísima. Un verdadero manual de enseñanzas concretas para la vida práctica de cada día: Los deberes. Y una colección copiosa de ejemplos muy bien traídos para reforzar e ilustrar brillantemente los consejos y dirección de un celoso pastor que, ante todo, busca la edificación moral, virtuosa, es decir sólidamente cristiana, de toda su grey. ¿No sería el nervio vital de ejemplos como estos lo que tanto atraía al convertido en Milán?

El libro termina gratamente con la inclusión de nueve himnos de san Ambrosio, sencillos pero enjundiosos, varios de los cuales se conservan en Liturgia de las horas.

Agradecemos el trabajo y oportunidad del traductor Julio Picasso que ha puesto en nuestras mansos una obra que no debió estar cerrada para el gran público de la lengua española. Hoy, Los deberes que con sabiduría escribió san Ambrosio para nosotros, gracias a Picasso y a la Universidad Católica Sedes Sapientiae este libro ha recuperado, al fin, la importancia y la actualidad que merecía. 